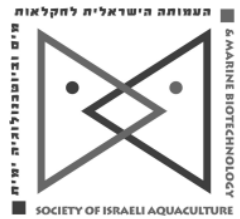

The IJA appears exclusively as a peerreviewed on-line Open Access journal at http://www.siamb.org.il Sale of IJA papers is strictly forbidden.

\title{
Effect of Dietary Canola Oil Level on Fatty Acid Composition of Rainbow Trout (Oncorhynchus mykiss L.)
}

\author{
Seval Dernekbaşi ${ }^{1 *}$, İsmihan Karayücel ${ }^{1}$, Abdullah Öksüzz $^{2}$ \\ ${ }^{1}$ University of Sinop, Faculty of Aquaculture and Fisheries, Department of \\ Aquaculture, 57000 Sinop, Turkey
}

${ }^{2}$ Department of Fisheries and Fish Processing Technology, Faculty of Fisheries and Aquaculture, Mustafa Kemal University, 31200 İskenderun, Hatay, Turkey

(Received 19.2.10, Accepted 30.4.10)

Key words: rainbow trout, Oncorhynchus mykiss, canola oil, chemical composition, fatty acids

\begin{abstract}
The effects of different levels of dietary canola oil on fatty acid composition of rainbow trout (Oncorhynchus mykiss) were investigated. Five experimental diets with equal protein $(47 \%)$ and lipid $(17 \%)$ contents were formulated for rainbow trout with a mean weight of $119 \pm 0.17 \mathrm{~g}$. Canola oil was used to replace 0 , $25 \%, 50 \%, 75 \%$, or $100 \%$ of the fish oil in the control diet. Fish were fed twice daily to satiation for 70 days. At the end of the study, fatty acid compositions in the trout body mirrored the fatty acid compositions of the experimental diets. The highest fatty acids were palmitic acid (C16:0), oleic acid (C18:1n-9), linoleic acid (C18:2n-6), and docosahexaenoic acids (C22:6n-3). The study showed that, under our test conditions, canola oil can replace $100 \%$ of fish oil with no negative effect on the chemical or fatty acid composition of rainbow trout.
\end{abstract}

* Corresponding author. Tel: +90-368-2876265, fax: +90-368-2876255, e-mail: sevalyaman@hotmail.com 


\section{Introduction}

The cardiovascular health benefits of consuming salmon and trout are well established. In the past 20 years, consumption and production of salmonid fish has increased remarkably. The importance of consuming salmonids derives especially from the existence of eicosapentaenoic (20:5n-3; EPA) and docosahexaenoic (22:6n-3; DHA) acids which are among the essential n-3 polyunsaturated fatty acids (PUFA; Drew et al., 2007). EPA and DHA have a strong effect on preventing cardiac disease and hypertension especially because of their decreasing effects on coagulation in veins (Harper and Jacobson, 2001; Daviglus et al., 2002). In addition, the health benefits of fish oil include its ability to treat high cholesterol, depression, low immunity, cancer, macular degeneration, and ulcers. Most of these health benefits can be attributed to the presence of DHA and EPA. Other useful essential fatty acids include a-linolenic acid (ALnA) and $\gamma$-linolenic acid (GLnA).

The fatty acid composition of fish reflects the fatty acid composition of its diet. A primary source of lipid in aquaculture feeds is fish oil (Grant et al., 2008). Fish oil is an excellent lipid source in fish diets because of its high proportion of long-chain n-3 fatty acids, especially DHA and EPA, which are nutritionally essential to teleosts (NRC, 1993). The disadvantages of fish oil as a source of dietary lipid for fish is its high cost and vulnerability to oxidation (Pozernick and Wiegand, 1997). Further, while total production of fish oil is static, the aquaculture industry is rapidly growing and using an everincreasing proportion of this commodity. Thus comes the incentive to formulate diets that contain less expensive and more stable lipid sources without compromising fish health.

Alternative plant oil sources (e.g., corn, sunflower, linseed) that are easy to produce, economical, and rich in essential fatty acids have been investigated as an alternative to fish oil in diets for fish species. Plant oils that are rich in n-6 fatty acids do not affect growth or whole body fatty acid composition in many farmed freshwater species, including rainbow trout (Yigit and Olmez, 2009; Karayucel and Dernekbasi, 2010). Thus, the aim of the present study was to determine the impact of up to $100 \%$ replacement of dietary fish oil by canola oil on the fatty acid composition of rainbow trout, Oncorhynchus mykiss.

\section{Materials and Methods}

Experimental diets. Raw fishmeal, extracted soybean meal, wheat flour, fish oil, sunflower seed meal, corn protein, and vitamin-mineral premix were purchased from a commercial feed firm (Sibal A.Ş. Black Sea Feed, Sinop, Turkey). Canola oil was obtained from a commercial feed firm (Çevresel Kimya San. Tic. A.Ş., Edincik, Bandırma, Turkey). Five experimental diets (47\% protein, $17 \%$ lipid, dry-weight basis) were prepared in which 0, 25\%, $50 \%, 75 \%$, or $100 \%$ of the fish oil was replaced by canola oil (Table 1 ). Diets were stored at $-20^{\circ} \mathrm{C}$ in air-tight bags until use.

Fish maintenance and experimental design. Rainbow trout $(119 \pm 0.17 \mathrm{~g})$ were obtained from a commercial farm in Samsun, Turkey. The fish were transported to the research unit of the Faculty of Aquaculture and Fisheries 
Table 1. Ingredient and proximate compositions of the control and experimental diets.

\begin{tabular}{lccccc}
\hline & \multicolumn{5}{c}{ Canola oil (\%) } \\
\cline { 2 - 6 } Ingredient & 0 & 25 & 50 & 75 & 100 \\
\hline Fishmeal & 44.79 & 44.79 & 44.79 & 44.79 & 44.79 \\
Soybean meal & 23.12 & 23.12 & 23.12 & 23.12 & 23.12 \\
Wheat flour & 10.47 & 10.47 & 10.47 & 10.47 & 10.47 \\
Fish oil & 12.22 & 9.17 & 6.11 & 3.05 & - \\
Canola oil & - & 3.05 & 6.11 & 9.17 & 12.22 \\
Sunflower seed meal & 6.50 & 6.50 & 6.50 & 6.50 & 6.50 \\
Corn protein & 2.00 & 2.00 & 2.00 & 2.00 & 2.00 \\
Vitamin premix* & 0.20 & 0.20 & 0.20 & 0.20 & 0.20 \\
Mineral premix* & 0.20 & 0.20 & 0.20 & 0.20 & 0.20 \\
Chrome oxide (Cr$\left.{ }_{2} \mathrm{O}_{3}\right)$ & 0.50 & 0.50 & 0.50 & 0.50 & 0.50 \\
Proximate composition & & & & & \\
Moisture (\%) & $6.87 \pm 0.37$ & $5.98 \pm 0.14$ & $5.38 \pm 0.29$ & $4.75 \pm 0.15$ & $5.20 \pm 0.26$ \\
Ash (\%) & $7.34 \pm 0.10$ & $7.02 \pm 0.04$ & $7.58 \pm 0.13$ & $7.92 \pm 0.05$ & $7.28 \pm 0.21$ \\
Protein (\%) & $47.34 \pm 0.15$ & $47.37 \pm 0.12$ & $47.54 \pm 0.04$ & $47.28 \pm 0.03$ & $47.30 \pm 0.09$ \\
Lipid (\%) & $17.50 \pm 0.05$ & $17.51 \pm 0.07$ & $17.50 \pm 0.05$ & $17.50 \pm 0.04$ & $17.47 \pm 0.04$ \\
Fiber (\%) & $2.25 \pm 0.062$ & $2.24 \pm 0.05$ & $2.32 \pm 0.03$ & $2.27 \pm 0.03$ & $2.33 \pm 0.01$ \\
Gross energy (kJ/g) & 21.26 & 21.47 & 21.48 & 21.52 & 21.53 \\
\hline * Vitamin-mineral premix (mg/kg premix): vitamin A 210000 IU: Vitamin & 35000
\end{tabular}

* Vitamin-mineral premix (mg/kg premix): vitamin A $210000 \mathrm{IU}$; Vitamin $D_{3} 35000$ IU; vitamin E $7000 \mathrm{mg}$; vitamin $\mathrm{K}_{3} 322 \mathrm{mg}$; vitamin $\mathrm{B}_{1} 588 \mathrm{mg}$; vitamin $\mathrm{B}_{2} 252 \mathrm{mg}$; vitamin $B_{6} 294 \mathrm{mg}$; vitamin $B_{12} 826 \mathrm{mcg}$; niacin $1400 \mathrm{mg}$; biotin $7583 \mathrm{mcg}$; folic acid $182 \mathrm{mg}$; pantothenic acid $1722 \mathrm{mg}$; inositol $17220 \mathrm{mg}$; vitamin C $933.31 \mathrm{mg}$; Ca $1414 \mathrm{mg}$

(University of Sinop, Turkey) and placed in three 1000-I rectangular tanks for acclimation. After acclimation, fish were fasted for one day, batch weighed, and randomly distributed among fifteen circular fiberglass tanks $(60 \times 80 \mathrm{~cm})$ containing approximately 300 liters of water at a density of 30 fish per tank. The fish were individually weighed at the end of the experiment with a $1 \mathrm{~g}$ sensitive electronic balance. Temperature, $\mathrm{pH}$, and dissolved oxygen were monitored weekly.

Feeding. The experiment was conducted in triplicate in randomly assigned tanks. Fish were hand fed twice a day (9:00 and 17:00) to apparent satiety under a natural light regime for 70 days. Care was taken to ensure that all fish ingested feed. After feeding, the remaining feed was weighed and the daily feed amount determined.

Chemical analyses. The chemical compositions of the diets were analyzed by standard methods (AOAC, 1995): dry matter after drying at $105^{\circ} \mathrm{C}$ for 24 $h$, crude protein by the Kjeldahl method after acid digestion $(N \times 6.25)$, crude lipid after extraction with petroleum ether by the Soxhlet method, and ash by incineration at $550^{\circ} \mathrm{C}$ in a muffle furnace for $12 \mathrm{~h}$.

Fatty acid analysis. Total lipid was determined by modified Bligh and Dyer Method (Hanson and Olley, 1963). Fatty acid methyl esters of the dietary lipids and fish fillets were saponified by heating 30-40 $\mathrm{mg}$ of the lipid with 2 $\mathrm{ml} 0.5 \mathrm{M}$ methanolic $\mathrm{KOH}$ at $100^{\circ} \mathrm{C}$ for $7 \mathrm{~min}$. A further $1.5 \mathrm{ml}$ of methanolic 
$\mathrm{BF}_{3}$ was added and the mixture was heated for another 5 min. FAMEs were extracted with $2 \mathrm{ml}$ iso-octane and extracts were decanted into an amber vial. FAMEs were separated and identified as described in Oksuz et al. (2009).

Statistical analysis. Data are presented as means \pm SD $(n=3)$. Statistical analyses were performed using Minitab 13 Software for Windows. Effects of dietary canola oil on the tissue fatty acid compositions were analyzed by oneway ANOVA. Data identified as non-homogeneous (Levene's test) were subjected to square root transformation before analyses. The level of significant difference was set at $p<0.05$.

\section{Results}

The fatty acid compositions of the diets differed in both individual fatty acids and major fatty acid classes (Table 2). The $100 \%$ diet contained the lowest amount of saturated fatty acids (SFA). Palmitic acid was highest SFA in all diets and decreased as the amount of canola oil increased. Mono-unsaturated fatty acid was highest in the $100 \%$ diet, with oleic acid constituting the highest constituent. The n-3/n-6 ratio was highest in the 0 canola group and lowest in the $100 \%$ group. The fatty acid contents of all fish groups were satisfactory (Table 3 ). Relationships between some fatty acid concentrations of the diets and their respective fish fillets are given in Fig. 1.

Table 2. Levels of saturated (SFA), mono-unsaturated (MUFA), and polyunsaturated (PUFA) fatty acids (\% of total fatty acids) in rainbow trout diets containing different levels of canola oil as replacement for fish oil.

\begin{tabular}{|c|c|c|c|c|c|}
\hline \multirow{2}{*}{ Fatty acid } & \multicolumn{5}{|c|}{ Replacement level (\%) } \\
\hline & 0 & 25 & 50 & 75 & 100 \\
\hline C14:0 (myristic) & $6.31 \pm 0.01^{\mathrm{e}}$ & $5.01 \pm 0.14^{d}$ & $3.83 \pm 0.05^{c}$ & $2.86 \pm 0.05^{b}$ & $1.45 \pm 0.02^{\mathrm{a}}$ \\
\hline C15:0 & $0.89 \pm 0.02^{d}$ & $0.71 \pm 0.02^{\mathrm{c}}$ & $0.56 \pm 0.01^{b}$ & $0.42 \pm 0.00^{\mathrm{a}}$ & ND \\
\hline C16:0 (palmitic) & $20.14 \pm 0.42^{\mathrm{e}}$ & $16.85 \pm 0.49^{d}$ & $14.79 \pm 0.31^{c}$ & $13.29 \pm 0.05^{b}$ & $11.03 \pm 0.09^{\mathrm{a}}$ \\
\hline C17:0 & $0.82 \pm 0.01^{d}$ & $0.66 \pm 0.02^{c}$ & $0.55 \pm 0.01^{b}$ & $0.34 \pm 0.04^{\mathrm{a}}$ & ND \\
\hline C18:0 (stearic) & $4.62 \pm 0.08^{d}$ & $4.15 \pm 0.09^{c}$ & $3.78 \pm 0.04^{b}$ & $3.57 \pm 0.00^{\mathrm{b}}$ & $3.05 \pm 0.09^{a}$ \\
\hline C20:0 & $1.35 \pm 0.05^{\mathrm{d}}$ & $1.20 \pm 0.04^{\mathrm{cd}}$ & $1.05 \pm 0.06^{\mathrm{bc}}$ & $0.95 \pm 0.02^{b}$ & $0.71 \pm 0.01^{a}$ \\
\hline $\mathrm{C} 22: 0$ & ND & $0.11 \pm 0.11$ & ND & ND & ND \\
\hline C23:0 & ND & $0.07 \pm 0.07^{a}$ & $0.19 \pm 0.098^{a}$ & ND & ND \\
\hline$C 24: 0$ & ND & ND & $0.08 \pm 0.08$ & ND & ND \\
\hline Total SFA & $34.13 \pm 0.51^{\mathrm{e}}$ & $28.76 \pm 0.49^{d}$ & $24.83 \pm 0.28^{c}$ & $21.43 \pm 0.06^{b}$ & $16.24 \pm 0.38^{\mathrm{a}}$ \\
\hline C14:1 & ND & $0.07 \pm 0.07$ & $0.11 \pm 0.06$ & ND & ND \\
\hline C16:1 n-7 (palmitoleic) & $6.68 \pm 0.04^{e}$ & $5.24 \pm 0.05^{d}$ & $4.16 \pm 0.07^{c}$ & $3.18 \pm 0.10^{\mathrm{b}}$ & $1.71 \pm 0.04^{\mathrm{a}}$ \\
\hline C16:1 n-9 & ND & $0.07 \pm 0.07$ & $0.13 \pm 0.063$ & ND & ND \\
\hline C17:1 n-10 & $0.15 \pm 0.015$ & $0.29 \pm 0.14$ & $0.24 \pm 0.12$ & $0.35 \pm 0.03$ & ND \\
\hline C18:1 n-9 (oleic) & $17.93 \pm 0.49^{a}$ & $25.23 \pm 0.70^{\mathrm{b}}$ & $30.44 \pm 0.85^{c}$ & $35.89 \pm 0.37^{d}$ & $45.63 \pm 0.41^{\mathrm{e}}$ \\
\hline$C 18: 1 n-7$ & $1.70 \pm 0.85$ & $0.07 \pm 0.07$ & $0.16 \pm 0.08$ & $0.25 \pm 0.00$ & ND \\
\hline C20:1 & $0.37 \pm 0.19^{a}$ & $0.97 \pm 0.17^{b}$ & $1.19 \pm 0.06^{\mathrm{b}}$ & $1.37 \pm 0.01^{\mathrm{b}}$ & $1.46 \pm 0.04^{\mathrm{b}}$ \\
\hline$C 22: 1 \mathrm{n}-9$ & ND & $0.26 \pm 0.15^{\mathrm{a}}$ & $0.97 \pm 0.06^{b}$ & $1.00 \pm 0.03^{b}$ & $0.94 \pm 0.02^{b}$ \\
\hline Total MUFA & $26.83 \pm 0.47^{a}$ & $32.20 \pm 0.24^{\mathrm{b}}$ & $37.40 \pm 0.42^{c}$ & $42.04 \pm 0.11^{d}$ & $49.74 \pm 0.34^{\mathrm{e}}$ \\
\hline C16:2 n-4 & $0.10 \pm 0.10$ & $0.15 \pm 0.08$ & $0.12 \pm 0.06$ & $0.17 \pm 0.05$ & ND \\
\hline$C 16: 4 n-1$ & ND & $0.06 \pm 0.06$ & $0.10 \pm 0.05$ & $0.30 \pm 0.15$ & ND \\
\hline C18:2 n-6 (linoleic) & $7.31 \pm 0.15^{\mathrm{a}}$ & $9.99 \pm 0.20^{\mathrm{b}}$ & $12.67 \pm 0.18^{c}$ & $15.22 \pm 0.13^{d}$ & $19.39 \pm 0.10^{\mathrm{e}}$ \\
\hline
\end{tabular}


Table 2. Levels of saturated (SFA), mono-unsaturated (MUFA), and polyunsaturated (PUFA) fatty acids ( $\%$ of total fatty acids) in rainbow trout diets containing different levels of canola oil as replacement for fish oil.

\begin{tabular}{lccccc}
\hline \multirow{2}{*}{ Fatty acid } & \multicolumn{5}{c}{ Replacement level (\%) } \\
\cline { 2 - 6 } & 0 & 25 & 50 & 75 & 100 \\
\hline C18:3 n-6 (Y linolenic) & $\mathrm{ND}$ & $0.11 \pm 0.11$ & $0.20 \pm 0.10$ & $0.26 \pm 0.01$ & $\mathrm{ND}$ \\
C18:3 n-3 (linolenic) & $1.29 \pm 0.10^{\mathrm{a}}$ & $2.58 \pm 0.02^{\mathrm{b}}$ & $3.73 \pm 0.07^{\mathrm{c}}$ & $4.76 \pm 0.06^{\mathrm{d}}$ & $5.91 \pm 0.15^{\mathrm{e}}$ \\
C18:4 n-3 & $1.39 \pm 0.02^{\mathrm{d}}$ & $1.08 \pm 0.01^{\mathrm{c}}$ & $0.87 \pm 0.04^{\mathrm{b}}$ & $0.59 \pm 0.01^{\mathrm{b}}$ & $0.23 \pm 0.12^{\mathrm{a}}$ \\
C20:2 & $\mathrm{ND}$ & $0.06 \pm 0.06$ & $0.14 \pm 0.07$ & $0.18 \pm 0.02$ & $\mathrm{ND}$ \\
C20:3 n-3 & $0.31 \pm 0.16^{\mathrm{a}}$ & $0.36 \pm 0.01$ & $0.32 \pm 0.03$ & $0.28 \pm 0.04$ & $\mathrm{ND}$ \\
C20:3 n-6 & $\mathrm{ND}$ & $0.21 \pm 0.21$ & $0.20 \pm 0.20$ & $\mathrm{ND}$ & $\mathrm{ND}$ \\
C20:4 n-6 & $0.83 \pm 0.01$ & $0.44 \pm 0.22$ & $0.36 \pm 0.18$ & $0.50 \pm 0.02$ & $0.26 \pm 0.16$ \\
C20:5 n-3 (EPA) & $9.26 \pm 0.30^{\mathrm{e}}$ & $7.29 \pm 0.02^{\mathrm{d}}$ & $5.49 \pm 0.07^{\mathrm{c}}$ & $4.18 \pm 0.03^{\mathrm{b}}$ & $2.32 \pm 0.06^{\mathrm{a}}$ \\
C22:4 & $0.19 \pm 0.19$ & $0.29 \pm 0.15$ & $0.37 \pm 0.02$ & $0.24 \pm 0.02$ & $\mathrm{ND}$ \\
C22:5 n-3 & $0.81 \pm 0.06^{\mathrm{b}}$ & $0.66 \pm 0.03^{\mathrm{b}}$ & $0.57 \pm 0.08^{\mathrm{b}}$ & $0.38 \pm 0.03^{\mathrm{a}}$ & $\mathrm{ND}$ \\
C22:6 n-3 (DHA) & $16.61 \pm 0.83^{\mathrm{e}}$ & $14.49 \pm 0.06^{\mathrm{d}}$ & $10.97 \pm 0.09^{\mathrm{c}}$ & $8.85 \pm 0.10^{\mathrm{b}}$ & $5.91 \pm 0.11^{\mathrm{a}}$ \\
Total n-3 PUFA & $29.67 \pm 0.62^{\mathrm{e}}$ & $26.46 \pm 0.07^{\mathrm{d}}$ & $21.95 \pm 0.09^{\mathrm{c}}$ & $19.04 \pm 0.19^{\mathrm{b}}$ & $14.37 \pm 0.24^{\mathrm{a}}$ \\
Total n-6 PUFA & $8.14 \pm 0.16^{\mathrm{a}}$ & $10.75 \pm 0.17^{\mathrm{b}}$ & $13.43 \pm 0.10^{\mathrm{c}}$ & $15.98 \pm 0.12^{\mathrm{d}}$ & $19.65 \pm 0.13^{\mathrm{e}}$ \\
Total PUFA & $38.10 \pm 0.69^{\mathrm{c}}$ & $37.77 \pm 0.27^{\mathrm{c}}$ & $36.11 \pm 0.14^{\mathrm{b}}$ & $35.91 \pm 0.21^{\mathrm{b}}$ & $34.02 \pm 0.12^{\mathrm{a}}$ \\
n-3/n-6 & $3.65 \pm 0.11^{\mathrm{e}}$ & $2.46 \pm 0.04^{\mathrm{d}}$ & $1.64 \pm 0.02^{\mathrm{c}}$ & $1.19 \pm 0.02^{\mathrm{b}}$ & $0.73 \pm 0.01^{\mathrm{a}}$ \\
\hline Different SUPersCripts
\end{tabular}

Different superscripts within a row denote significant differences. ND $=$ not detected

Table 3. Levels of saturated (SFA), mono-unsaturated (MUFA), and poly-unsaturated (PUFA) fatty acids (\% of total fatty acids) in muscle of rainbow trout fed diets containing different levels of canola oil as replacement for fish oil.

\begin{tabular}{lccccc}
\hline \multirow{2}{*}{ Fatty acid } & \multicolumn{5}{c}{ Replacement level (\%) } \\
\cline { 2 - 6 } C14:0 (myristic) & $4.79 \pm 0.07^{\mathrm{a}}$ & $3.93 \pm 0.03^{\mathrm{b}}$ & $3.38 \pm 0.21^{\mathrm{c}}$ & $2.66 \pm 0.06^{\mathrm{d}}$ & $3.57 \pm 1.38^{\mathrm{c}}$ \\
C15:0 & $0.68 \pm 0.01^{\mathrm{a}}$ & $0.55 \pm 0.02^{\mathrm{b}}$ & $0.49 \pm 0.02^{\mathrm{b}}$ & $0.39 \pm 0.00^{\mathrm{c}}$ & $0.51 \pm 0.17^{\mathrm{b}}$ \\
C16:0 (palmitic) & $18.41 \pm 0.36^{\mathrm{a}}$ & $17.14 \pm 0.40^{\mathrm{a}}$ & $17.30 \pm 0.29^{\mathrm{a}}$ & $15.94 \pm 0.27^{\mathrm{b}}$ & $15.98 \pm 1.65^{\mathrm{ab}}$ \\
C17:0 & $0.58 \pm 0.09^{\mathrm{a}}$ & $0.43 \pm 0.057^{\mathrm{a}}$ & $0.11 \pm 0.11^{\mathrm{b}}$ & $0.28 \pm 0.05^{\mathrm{ab}}$ & $0.39 \pm 0.24^{\mathrm{ab}}$ \\
C18:0 (stearic) & $4.54 \pm 0.19$ & $4.27 \pm 0.09$ & $4.33 \pm 0.14$ & $4.34 \pm 0.15$ & $4.22 \pm 0.16$ \\
C20:0 & $0.72 \pm 0.03^{\mathrm{a}}$ & $0.57 \pm 0.02^{\mathrm{b}}$ & $0.55 \pm 0.04^{\mathrm{bc}}$ & $0.46 \pm 0.02^{\mathrm{c}}$ & $0.77 \pm 0.25^{\mathrm{a}}$ \\
C22:0 & $\mathrm{ND}$ & $\mathrm{ND}$ & $\mathrm{ND}$ & $\mathrm{ND}$ & $0.71 \pm 0.71$ \\
C23:0 & $0.30 \pm 0.04$ & $0.28 \pm 0.17$ & $0.09 \pm 0.09$ & $0.20 \pm 0.19$ & $0.12 \pm 0.12$ \\
C24:0 & $1.55 \pm 0.06^{\mathrm{a}}$ & $0.86 \pm 0.43^{\mathrm{c}}$ & $1.12 \pm 0.03^{\mathrm{b}}$ & $0.79 \pm 0.03^{\mathrm{c}}$ & $0.42 \pm 0.21^{\mathrm{d}}$ \\
Total SFA & $31.27 \pm 0.77^{\mathrm{a}}$ & $28.03 \pm 0.19^{\mathrm{b}}$ & $27.37 \pm 0.52^{\mathrm{b}}$ & $25.06 \pm 0.31^{\mathrm{c}}$ & $26.69 \pm 3.64^{\mathrm{c}}$ \\
\hline C14:1 & $0.07 \pm 0.07$ & $\mathrm{ND}$ & $\mathrm{ND}$ & $\mathrm{ND}$ & $0.09 \pm 0.09$ \\
C16:1 n-7 (palmitoleic) & $6.23 \pm 0.24^{\mathrm{a}}$ & $5.32 \pm 0.17^{\mathrm{b}}$ & $4.67 \pm 0.44^{\mathrm{bc}}$ & $3.88 \pm 0.09^{\mathrm{c}}$ & $3.33 \pm 1.92^{\mathrm{d}}$ \\
C16:1 n-9 & $0.16 \pm 0.08$ & $\mathrm{ND}$ & $\mathrm{ND}$ & $0.12 \pm 0.12$ & $0.12 \pm 0.12$ \\
C17:1 n-10 & $0.46 \pm 0.03^{\mathrm{a}}$ & $0.28 \pm 0.14^{\mathrm{b}}$ & $\mathrm{ND}$ & $0.33 \pm 0.01^{\mathrm{b}}$ & $0.17 \pm 0.17^{\mathrm{c}}$ \\
C18:1 n-9 (oleic) & $20.09 \pm 1.26^{\mathrm{a}}$ & $25.18 \pm 1.23^{\mathrm{b}}$ & $26.62 \pm 0.84^{\mathrm{b}}$ & $30.03 \pm 0.97^{\mathrm{d}}$ & $27.59 \pm 4.59^{\mathrm{c}}$ \\
C18:1 n-7 & $1.12 \pm 0.88^{\mathrm{a}}$ & $1.02 \pm 1.02^{\mathrm{b}}$ & $0.07 \pm 0.07^{\mathrm{b}}$ & $0.08 \pm 0.08^{\mathrm{ab}}$ & $\mathrm{ND}$ \\
C20:1 & $1.23 \pm 0.05^{\mathrm{a}}$ & $1.35 \pm 0.13^{\mathrm{a}}$ & $1.57 \pm 0.25^{\mathrm{b}}$ & $1.69 \pm 0.09^{\mathrm{b}}$ & $1.31 \pm 0.41^{\mathrm{a}}$ \\
C20:1 n-9 & $0.13 \pm 0.07$ & $\mathrm{ND}$ & $\mathrm{ND}$ & $\mathrm{ND}$ & $\mathrm{ND}$ \\
C22:1 n-9 & $\mathrm{ND}$ & $0.14 \pm 0.07$ & $0.09 \pm 0.09$ & $0.28 \pm 0.15$ & $0.36 \pm 0.18$ \\
Total MUFA & $29.49 \pm 0.70^{\mathrm{a}}$ & $33.29 \pm 0.27^{\mathrm{b}}$ & $33.02 \pm 1.48^{\mathrm{b}}$ & $36.41 \pm 1.02^{\mathrm{c}}$ & $32.97 \pm 3.43^{\mathrm{b}}$ \\
\hline C16:2 n-4 & $0.14 \pm 0.07$ & $\mathrm{ND}$ & $\mathrm{ND}$ & $\mathrm{ND}$ & $0.10 \pm 0.09$ \\
C16:4 n-1 & $0.24 \pm 0.19^{\mathrm{c}}$ & $0.34 \pm 0.17^{\mathrm{b}}$ & $0.47 \pm 0.02^{\mathrm{a}}$ & $0.25 \pm 0.01^{\mathrm{c}}$ & $0.20 \pm 0.10^{\mathrm{d}}$ \\
\hline
\end{tabular}


Table 3. Levels of saturated (SFA), mono-unsaturated (MUFA), and poly-unsaturated (PUFA) fatty acids (\% of total fatty acids) in muscle of rainbow trout fed diets containing different levels of canola oil as replacement for fish oil.

\begin{tabular}{lccccc}
\hline \multirow{2}{*}{ Fatty acid } & \multicolumn{5}{c}{ Replacement level (\%) } \\
\cline { 2 - 5 } & 0 & 25 & 50 & 75 & 100 \\
\hline C18:2 n-6 (linoleic) & $8.39 \pm 0.27^{\mathrm{a}}$ & $12.32 \pm 0.03^{\mathrm{b}}$ & $14.54 \pm 0.32^{\mathrm{c}}$ & $16.55 \pm 0.17^{\mathrm{e}}$ & $15.45 \pm 4.15^{\mathrm{d}}$ \\
C18:3 n-6 (Y linolenic) & $0.19 \pm 0.10$ & $0.11 \pm 0.11$ & $0.24 \pm 0.12$ & $0.60 \pm 0.07$ & $0.64 \pm 0.32$ \\
C18:3 n-3 (linolenic) & $0.45 \pm 0.37^{\mathrm{a}}$ & $2.02 \pm 0.01^{\mathrm{b}}$ & $2.63 \pm 0.17^{\mathrm{c}}$ & $2.81 \pm 0.04^{\mathrm{c}}$ & $2.65 \pm 0.63^{\mathrm{c}}$ \\
C18:4 n-3 & $0.78 \pm 0.07$ & $0.76 \pm 0.17$ & $0.68 \pm 0.12$ & $0.66 \pm 0.10$ & $0.92 \pm 0.17$ \\
C20:2 & $0.65 \pm 0.19^{\mathrm{a}}$ & $0.76 \pm 0.02^{\mathrm{b}}$ & $0.99 \pm 0.07^{\mathrm{c}}$ & $1.06 \pm 0.04^{\mathrm{d}}$ & $0.78 \pm 0.39^{\mathrm{b}}$ \\
C20:3 n-6 & $0.35 \pm 0.13^{\mathrm{a}}$ & $0.46 \pm 0.03^{\mathrm{b}}$ & $0.68 \pm 0.07^{\mathrm{b}}$ & $0.81 \pm 0.12^{\mathrm{b}}$ & $0.71 \pm 0.36^{\mathrm{b}}$ \\
C20:3 n-3 & $0.61 \pm 0.016^{\mathrm{a}}$ & $0.37 \pm 0.19^{\mathrm{b}}$ & $0.42 \pm 0.08^{\mathrm{b}}$ & $0.40 \pm 0.03^{\mathrm{b}}$ & $0.33 \pm 0.07^{\mathrm{b}}$ \\
C20:4 n-6 & $0.72 \pm 0.00^{\mathrm{a}}$ & $0.63 \pm 0.04^{\mathrm{b}}$ & $0.67 \pm 0.17^{\mathrm{abc}}$ & $0.69 \pm 0.06^{\mathrm{abc}}$ & $0.84 \pm 0.03^{\mathrm{c}}$ \\
C20:5 n-3 (EPA) & $4.60 \pm 0.02^{\mathrm{d}}$ & $3.51 \pm 0.09^{\mathrm{c}}$ & $3.02 \pm 0.20^{\mathrm{b}}$ & $2.20 \pm 0.01^{\mathrm{a}}$ & $3.66 \pm 2.56^{\mathrm{c}}$ \\
C22:4 & $0.38 \pm 0.01^{\mathrm{b}}$ & $0.25 \pm 0.13^{\mathrm{b}}$ & $0.11 \pm 0.11^{\mathrm{a}}$ & $0.32 \pm 0.02^{\mathrm{a}}$ & $0.29 \pm 0.16^{\mathrm{a}}$ \\
C22:5 n-3 & $\mathrm{ND}$ & $0.42 \pm 0.42^{\mathrm{a}}$ & $\mathrm{ND}$ & $\mathrm{ND}$ & $0.30 \pm 0.16^{\mathrm{a}}$ \\
C22:6 n-3 (DHA) & $16.28 \pm 0.18^{\mathrm{c}}$ & $14.67 \pm 0.72^{\mathrm{b}}$ & $13.95 \pm 1.94^{\mathrm{b}}$ & $11.17 \pm 0.95^{\mathrm{a}}$ & $11.67 \pm 2.53^{\mathrm{a}}$ \\
Total n-3 PUFA & $22.72 \pm 0.43^{\mathrm{a}}$ & $21.75 \pm 1.15^{\mathrm{a}}$ & $20.70 \pm 2.14^{\mathrm{ab}}$ & $17.24 \pm 0.96^{\mathrm{b}}$ & $19.53 \pm 4.39^{\mathrm{ab}}$ \\
Total n-6 PUFA & $9.65 \pm 0.34^{\mathrm{a}}$ & $13.52 \pm 0.15^{\mathrm{b}}$ & $16.13 \pm 0.07^{\mathrm{c}}$ & $18.65 \pm 0.39^{\mathrm{d}}$ & $17.64 \pm 4.85^{\mathrm{cd}}$ \\
Total PUFA & $33.78 \pm 0.46^{\mathrm{a}}$ & $36.62 \pm 0.80^{\mathrm{b}}$ & $38.40 \pm 2.12^{\mathrm{c}}$ & $37.52 \pm 1.17^{\mathrm{b}}$ & $38.54 \pm 0.65^{\mathrm{c}}$ \\
n-3/n-6 & $2.35 \pm 0.08^{\mathrm{d}}$ & $1.61 \pm 0.10^{\mathrm{c}}$ & $1.28 \pm 0.14^{\mathrm{b}}$ & $0.92 \pm 0.05^{\mathrm{a}}$ & $1.11 \pm 0.11^{\mathrm{b}}$ \\
\hline Different SUPersCripts
\end{tabular}

Different superscripts within a row denote significant differences. ND = not detected
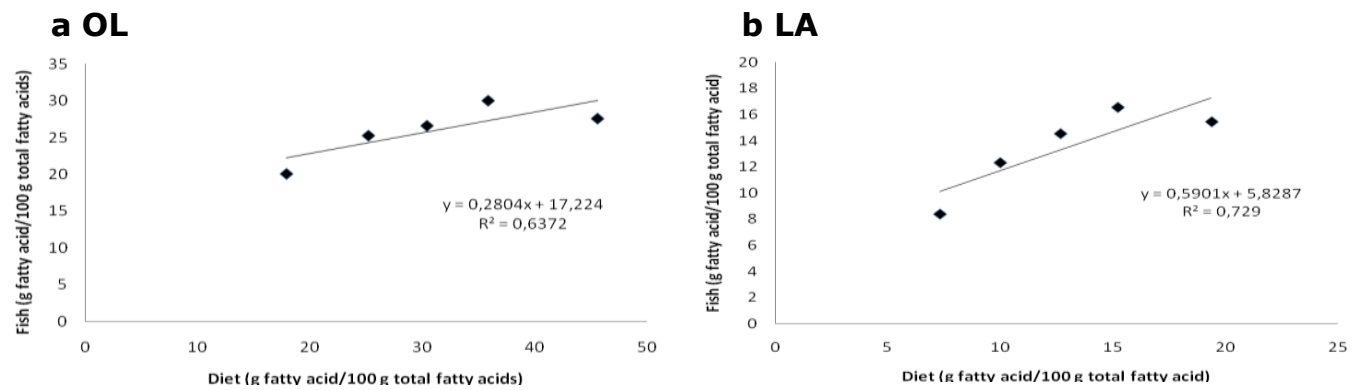

\section{c LnA}
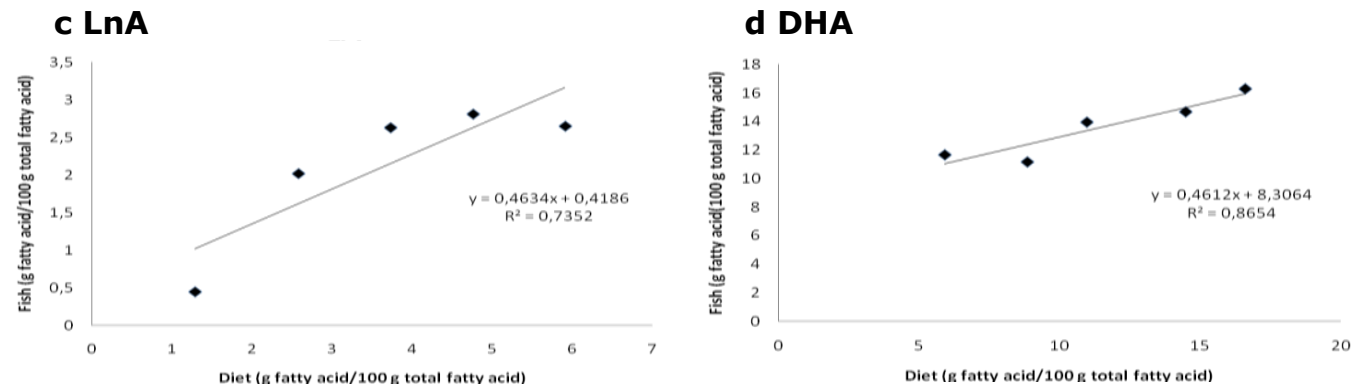

Fig. 1. Relationships between concentrations of (a) oleic acid (18:1n-9; OL), (b) linoleic acid (18:2n-6; LA), (c) linolenic acid (18:3n-3; LnA), and (d) docosahexaenoic acid $(22: 6 n-3 ; D H A)$ in diets containing different amounts of canola oil and fillets of the rainbow trout that consumed the respective diet. 


\section{Discussion}

In the present study, the fatty acid composition of rainbow trout consistently reflected the fatty acid compositions of the experimental diets, as reported earlier for seabream and seabass (Izquierdo et al., 2003) and Chinook salmon Grant et al., 2008).

Saturated fatty acids (SFA) in the fish flesh decreased as the level of dietary canola oil increased. Palmitic acid was the dominant SFA in both the experimental diets and the fish muscle, constituting $60 \%$ of the total SFA, followed by stearic (C18:0) and myristic (C14:0) acids. In teleosts, palmitic acid is dominant in almost all fish tissue (Aras et al., 2003). Thus, our result is consistent with studies on rainbow trout and other fish species which show that the dominance of palmitic acid is characteristic for fish (Caballero et al., 2002; Şener and Yıldız, 2003; Madrigal et al., 2005; Rinchard et al., 2007; Grant et al., 2008; Huang et al., 2008).

Generally, the dominant mono-unsaturated fatty acids (MUFA) in diets prepared from vegetal lipids are oleic and palmitoleic acid. When fed diets containing different vegetable oils and canola oil, oleic and palmitoleic acid are dominant in brown trout (Turchini et al., 2003) and rainbow trout (Greene and Selivonchick, 1990; Caballero et al., 2002; Liu et al., 2004; Madrigal et al., 2005). Likewise, in our study, the dominant MUFA were oleic and palmitoleic acids. Total MUFA is highly dependent on oleic acid, the main component of MUFA. MUFAs are the most stocked fatty acids in fish meat because they are substantially catabolized to provide metabolic energy for egg and gonad development (Sargent, 1995). Oleic acid constitutes the major portion of MUFA in seabass (Alasalvar et al., 2002), rainbow trout (Rinchard et al., 2007), seabream, Sparus aurata (Izquierdo et al., 2003), Chinook salmon (Huang et al., 2008), and Atlantic salmon (Bell et al., 2003).

The most abundant fatty acids in both the diets and the fish were polyunsaturated (PUFA). The most abundant PUFA were linoleic acid, linolenic acid, EPA, and DHA. The formulated diets were isonitrogenic and isolipidic and only the rates of fish oil and canola differed among feed ingredients. Increasing the proportion of vegetable oil in a diet causes remarkable decreases in EPA and DHA (Francis et al., 2007). In the present study, linoleic and linolenic acids increased but EPA and DHA decreased in fish as the proportion of dietary canola oil increased, similar to results in rainbow trout (Greene and Selivonchick, 1990; Caballero et al., 2002; Drew et al., 2007), Atlantic salmon (Bell et al., 2001, 2003), Murray cod (Francis et al., 2007), and Chinook salmon (Grant et al., 2008).

Fishmeal, which was used primarily as a protein source, also contributed lipid, especially n-3 PUFA. In all the supplemented diets, n-3 PUFA derived from fishmeal. Therefore, the control group, which contained only fish oil, had the highest amount of n-3 PUFA, while n-6 PUFA was higher in groups fed diets containing canola oil.

Freshwater fish species generally require $n-3$ and $n-6$ fatty acids, especially linoleic and linolenic, in their diets (Martino et al., 2002; Tocher, 2003). Due to elongation and desaturation enzymes in freshwater fish, the n- 
$3 / \mathrm{n}-6$ ratio in freshwater fish is much lower than in marine fish (Borlongan and Benitez, 1992). In Murray cod fed diets with different rates of canola oil, n-3 and n- 6 desaturate enzyme activity and elongation rose (Francis et al., 2007). In our study, the linolineic acid concentration was lower in the fillet than in the diet. Linoleic and linolenic acids are essential for Oncorhynchus spp. at $2 \%$ of the diet (NRC, 1993). In our study, the linoleic and linolenic acids were high enough for supply the rainbow trout requirement.

EPA and DHA are the most abundant n-3 PUFA in most fish oils. Long chain fatty acids usually constitute one fourth to one third of fish oil, while PUFA rarely compose $5 \%$ and usually no more than $1 \%$ of vegetable oil (Beklevik, 2005). Fatty acid compositions in rainbow trout tissue are affected by the fatty acid composition of its diet (Dosanjh et al., 1988; Torstensen et al., 2000). However, when the fatty acids in the diet are closely related to the fatty acids stored in the fish fillet, specific acids are selectively held or used. Such is DHA, which shows higher fastening and separation in the fillet than in the diet (Bell et al., 2001). DHA was higher in all our diets and fish fillets than EPA, and was not affected as much as EPA by the variation in canola oil level, as earlier reported (Piedecausa et al., 2007).

Deficiency of essential fatty acids causes growth recession, high mortality, fin deformation, and increased eicosatrienoic acid (C20:3n-9) in rainbow trout. Since, no deficiency was observed in fish fed diets containing canola oil, we conclude that the amount of fishmeal in all diets was sufficient to meet the essential fatty acid requirements of rainbow trout. Further, total $n-3$ decreased and total n-6 increased as the level of canola oil approached $100 \%$. The $n-3 / n-6$ ratio should be over 1 (NCM, 1989). In the present study, the $n-$ $3 / n-6$ ratio reached the desired level in almost the groups. Thus, using canola oil to replace up to $100 \%$ of the fish oil in diets for rainbow trout does not unfavorably affect the fatty acid composition of the fish fillet.

\section{Acknowledgements}

This paper is a part of Seval Dernekbaşi's Ph.D. thesis. We extend our gratefulness to Osman Parlak, the owner of the Kuzey Su Ürünleri fish farm, for providing us the fish, and to Hatice Ünal for her help.

\section{References}

Alasalvar C., Taylor K.D.A., Zubcov E., Shah D.F. and M. Alexis, 2002. Differentiation of cultured and wild sea bass (Dicentrarchus labrax): total lipid content, fatty acid and trace mineral composition. Food Chem., 79:145-150.

AOAC, 1995. Official Methods of Analysis. 16th ed. Association of Official Analytical Chemists, Arlington, VA.

Aras N.M., Haliloğlu H.i்., Bayır A., Atamanalp M. and A.N. Sirkecioğlu, 2003. Karasu havzası yeşildere çayı olgun dere alabalıkları (Salmo trutta macrostigma, Dumeril, 1858) 'nda farklı dokuların yağ asidi kompozisyonlarının karşılaştırılması. Turkish J. Vet. Anim. Sci., 27:887-892.

Beklevik G., 2005. Farklı avlanma mevsimlerinin, deniz levreğinin (Dicentrarchus labrax, LINNE, 1758) kimyasal kompozisyonu ve dondurularak 
depolamada $\left(-18^{\circ} \mathrm{C}\right)$ kimyasal ve duyusal kalite kriterlerine etkileri. Ph.D. thesis, Çukurova Üniv., Fen Bilimleri Enstitüsü, Adana. 125 pp.

Bell J.G., McEvoy J., Tocher D.R., McGhee F., Campbell P.J. and J.R. Sargent, 2001. Replacement of fish oil with rapeseed oil in diets of Atlantic salmon (Salmo salar) affects tissue lipid compositions and hepatocyte fatty acid metabolism. J. Nutr., 131:1535-1543.

Bell J.G., Tocher D.R., Henderson R.J., Dick J.R. and V.O. Crampton, 2003. Altered fatty acid compositions in Atlantic salmon (Salmo salar) fed diets containing linseed and rapeseed oils can be partially restored by a subsequent fish oil finishing diet. J. Nutr., 133:2793-2801.

Borlongan I.G. and L.V. Benitez, 1992. Lipid and fatty acid composition of milkfish (Chanos chanos) grown in freshwater and seawater. Aquaculture, 104:79-89.

Caballero M.J., Obach G., Rosenlund G., Montero D., Gisvold M. and M.S. Izquierdo, 2002. Impact of different dietary lipid sources on growth, lipid digestibility, tissue fatty acid composition and histology of rainbow trout, Oncorhynchus mykiss. Aquaculture, 214:253-271.

Daviglus M., Sheeshka J. and E. Murkin, 2002. Health benefits from eating fish. Comments Toxicol., 8:345-374.

Dosanjh B.S., Higgs D.A., Plotnikoff M.D., Markert J.R. and J.T. Buckley, 1988. Preliminary evaluation of canola oil, pork lard and marine lipid singly and in combination as supplemental dietary lipid sources for juvenile fall Chinook salmon (Oncorhynchus tshawytscha). Aquaculture, 68:325-343.

Drew M.D., Ogunkoya A.E., Janz D.M. and A.G. Van Kessel, 2007. Dietary influence of replacing fish meal and oil with canola protein concentrate and vegetable oils on growth performance, fatty acid composition and organoclorine residues in rainbow trout (Oncorhynchus mykiss). Aquaculture, 267:260-268.

Francis D.S., Turchini G.M., Jones P.L. and S.S. De Silva, 2007. Growth performance, feed efficiency and fatty acid composition of juvenile Murray cod, Maccullochella peelii peelii, fed graded levels of canola and linseed oil. Aquacult. Nutr., 13:335-350.

Grant A.A.M., Baker D., Higgs D.A., Brauner C.J., Richards J.G., Balfry S.K. and P.M. Schulte, 2008. Effects of dietary canola oil level on growth, fatty acid composition and osmoregulatory ability of juvenile fall Chinook salmon (Oncorhynchus tshawytscha). Aquaculture, 277:303-312.

Greene D.H.S. and D.P. Selivonchick, 1990. Effects of dietary vegetable, animal and marine lipids on muscle lipid and hematology of rainbow trout (Oncorhynchus mykiss). Aquaculture, 89:165-182.

Hanson S.W.F. and J. Olley, 1963. Application of the Bligh and Dyer method of lipid extraction to tissue homogenates. Biochem. J., 89:101-102.

Harper R.A. and T.A. Jacobson, 2001. The fats of life: the role of omega-3 fatty acids in the prevention of coronary heart disease. Arch. Intern. Med., 161:2185-2192. 
Huang S.S.Y., Fu C.H.L., Higgs D.A., Balfry S.K., Schulte P.M. and C.J. Brauner, 2008. Effects of dietary canola oil level on growth performance, fatty acid composition and ionoregulatory development of spring Chinook salmon parr, Oncorhynchus tshawytscha. Aquaculture, 274:109-117.

Izquierdo M.S., Obach G., Arantzamendi L., Montero D., Robaina L. and G. Rosenlund, 2003. Dietary lipid sources for seabream and seabass: growth performance, tissue composition and flesh quality. Aquaculture Nutrition, 9:397-407.

Karayucel I. and S. Dernekbasi, 2010. Effect of dietary canola oil level on growth, feed utilization and body composition of rainbow trout (Oncorhynchus mykiss L.). The Israeli Journal of Aquaculture-Bamidgeh, 62(3):155-162.

Liu K.K.M., Barrows F.T., Hardy R.W. and F.M. Dong, 2004. Body composition, growth performance, and product quality of rainbow trout (Oncorhynchus mykiss) fed diets containing poultry fat, soybean/corn lecithin, or menhaden oil. Aquaculture, 238:309-328.

Madrigal J.F., Karalazos V., Campbell P.J., Bell J.G. and D.R. Tocher, 2005. Influence of dietary palm oil on growth, tissue fatty acid compositions, and fatty acid metabolism in liver and intestine in rainbow trout (Oncorhynchus mykiss). Aquacult. Nutr., 11:241-250.

Martino R.C., Cyrino J.E.P., Portz L. and L.C. Trugo, 2002. Performance and fatty acid composition of surubim (Pseudoplatystoma coruscans) fed diets with animal and plant lipids. Aquaculture, 209:233-246.

NCM, 1989. Nordic Nutrition Recommendations, $2^{\text {nd }}$ ed. Nordic Council of Ministers, Copenhagen.

NRC, 1993. Nutrient Requirements of Fish. Natl. Res. Council, Natl. Acad. Press, Washington DC. 114 pp.

Oksuz A., Ozyilmaz A., Aktas A., Gercek G. and J. Motte, 2009. Comparative study on proximate, mineral and fatty acid compositions of deep seawater rose shrimp (Parapenaeus longirostris, Lucas 1846) and golden shrimp (Plesionika martia, A. Milne-Edwards, 1883). J. Anim. Vet. Advances, 8(1):183-189.

Piedecausa M.A., Mazón M.J., Garciá B. and M.D. Hernández, 2007. Effects of total replacement of fish oil by vegetable oils in the diets of sharpsnout seabream (Diplodus puntazzo). Aquaculture, 263:211-219.

Pozernick M. and M.D. Wiegand, 1997. Use of canola oil in the feed of larval and juvenile goldfish, Carassius auratus (L.). Aquacult. Res., 28:75-83.

Rinchard J., Czesny S. and K. Dabrowski, 2007. Influence of lipid class and fatty acid deficiency on survival, growth, and fatty acid composition in rainbow trout juveniles. Aquaculture, 264:363-371.

Sargent J.R., 1995. Origins and functions of egg lipids: nutritional implications. pp. 353-372. In: N.R. Bromage, R.J. Roberts (eds.). Broodstock Management and Egg and Larval Quality. Blackwell, Oxford (in: Beklevik, 2005).

Şener E. and M. Yıldız, 2003. Effect of the different oil on growth performance and body composition of rainbow trout (Oncorhynchus mykiss W., 1792) juveniles. Turkish J. Fish. Aquat. Sci., 3:111-116. 
Tocher D.R., 2003. Metabolism and functions of lipids and fatty acids in teleost fish. Rev. Fish. Sci., 11:107-184.

Torstensen B.E., Lie O. and L. Frøyland, 2000. Lipid metabolism and tissue composition in Atlantic salmon (Salmo salar L.) -- effects of capelin oil, palm oil, and oleic acid-enriched sunflower oil as dietary lipid sources. Lipids, 35:653-664.

Turchini G.M., Mentasti T., Frøyland L., Orban E., Caprino F., Moretti V.M. and F. Valfré, 2003. Effects of alternative dietary lipid sources on performances, tissue chemical composition, mitochondrial fatty acid oxidation capabilities and sensory characteristics in brown trout (Salmo trutta L.). Aquaculture, 225:251-267.

Yigit N.O. and M. Olmez, 2009. Canola meal as an alternative protein source in diets for fry of tilapia (Oreochromis niloticus). Isr. J. Aquacult. Bamidgeh, 61(1):35-41. 